\title{
Traditional uses, nutrition, phytochemistry and various pharmacological properties of Indian wild pear (Review)
}

\author{
OM PRAKASH ${ }^{1,2}$, ATTAR SINGH CHAUHAN ${ }^{1,2}$ and VITHAL BALAVANT KUDACHIKAR ${ }^{1,2}$ \\ ${ }^{1}$ Fruits and Vegetable Technology, CSIR-Central Food Technological Research Institute, Mysuru, Karnataka 570020; \\ ${ }^{2}$ Academy of Scientific and Innovative Research (AcSIR), Ghaziabad, Uttar Pradesh 201002, India
}

Received March 4, 2021; Accepted August 24, 2021

DOI: $10.3892 / \mathrm{ijfn} .2021 .19$

\begin{abstract}
The consumption of wild edible fruits for nutritional and medicinal benefits has been known for a long time. These naturally occurring fruit plants can thrive well under adverse climatic conditions and are being harvested and marketed locally. Pyrus pashia (P. pashia; Buch.-Ham. ex D. Don; family, Rosaceae), commonly known as 'wild edible or Himalayan pear' is one of such underutilized trees. It is widely distributed in temperate regions up to an altitude of 2,000 $\mathrm{m}$ in Western Himalaya. It has broad applications in traditional therapeutics for the treatment of diseases, such as eye infections, sore throat, diarrhea, stomach disorders and other infectious diseases. Chlorogenic acid, flavan-3-ols, gallic acid, tannins, alkaloids, hydroquinone, terpenoids and its isomers have been isolated and identified from the leaf, fruit, flower and bark portion of $P$. pashia. The phytochemicals present in the P. pashia tree may be responsible for the traditional beneficial health effects of the plant. Numerous scientific studies on P. pashia have validated the general uses of the plant by the native population; however, the data on its pharmacological properties and the mechanisms involved are insufficient. The present review aimed to provide a critical evaluation of the distribution, traditional uses, phytochemicals present, pharmacological activities and nutritional value of different plant parts of P.pashia. Detailed research is required on individual phytochemicals present and toxicological studies at the gene level. In-depth molecular studies may also confirm the various pharmaceutical claims for the development of novel pharmaceutical drugs and functional food products.
\end{abstract}

Correspondence to: Dr Vithal Balavant Kudachikar, Fruits and Vegetable Technology, CSIR-Central Food Technological Research Institute, Cheluvamba Mansion, Valmiki Road, Opp. Railway Museum, Devaraja Mohalla, CFTRI Campus, Kajjihundi, Mysuru, Karnataka 570020, India

E-mail: vbkudachikar@cftri.res.in

Key words: Pyrus pashia Buch.-Ham. ex D. Don, traditional uses, nutritional value, phytochemicals, pharmacological activities

\section{Contents}

1. Introduction

2. Habitat and morphology

3. Traditional uses of various parts of P. pashia

4. Nutritive value

5. Phytochemistry and pharmacological properties

6. Conclusion and future perspectives

\section{Introduction}

The diverse ecosystems of the Indian subcontinent result from a wide variety of atmosphere, topological and natural conditions. India has a mega-biodiversity and includes $>15,000$ types of flowering plants (1). Over 3,000 authoritatively recorded plants hold extraordinary therapeutic potential (2). Apart from the cultivated food crops, forest floras contribute an invaluable source of important species. In the Indian subcontinent, the majority of provincial occupants rely on wild palatable organic products to meet their extra nourishment prerequisites. These naturally occurring fruits are nutritious and medicinally beneficial, and are harvested and marketed locally. The wild fruit trees can survive well under harsh climatic conditions and can be the source of genes or traits of resistant varieties, free from biotic and abiotic stress conditions. A number of underutilized plant species in the Himalayan region have long been a source of medicine and nutrition for millions of individuals. Pandey and Negi also reported that the world business earnings from natural medications and phytonutrients were $\sim 75$ billion in 2007 , and these exceeded $\$ 262.9$ billion by the year 2020 (3). Therefore, exploring underutilized fruits for medicinal benefits, food and small-scale food sectors may lead to the efficient use of these fruits.

One such underutilized plant is Pyrus pashia (P. pashia; Buch.-Ham. ex D. Don), a medium-sized fruiting tree, a member of the Rosaceae family, commonly known as Kainth. The other common names for P. pashia are Indian wild pear, Himalayan pear, Batangi, Molu, Tangai, Sohjhur, Sohait-syiar, Mehal, etc. $(4,5)$. In India, $P$. pashia is grown mainly in the Himalayan region (6). The plant is one of the essential underutilized species and is revered for its nutritional and medicinal potential. It has been used for various purposes, particularly as a herbal medicine, for the treatment of digestive ailments such 
as dyspepsia and dysmenorrhea (7). The leaves of P. pashia have been used as a health beverage in the Monpa community of the Tawang district of Arunachal Pradesh, India (8). In Chinese folk medicine, the branches and leaves have been utilized as anti-diarrheal agents. Its flowers are consumed not only as an herbal medicine for lowering blood lipid levels, but also as the most common edible flowers (9).

The present review aimed to provide comprehensive data on $P$. pashia plant science, various traditional uses, phytochemicals present, pharmacological properties, nutritional value, cytotoxicity and therapeutic potential. The present review highlights the current status, lacunae in data available, and assesses future research openings. All the existing data on $P$. pashia were collected using electronic media, publications in peer-reviewed journals, textbooks and government survey records. The present review may provide a scientific basis for future research on underutilized fruit, such as $P$. pashia and other parts of this species.

\section{Habitat and morphology}

The genus Pyrus belongs to the subfamily Maloideae (family Rosaceae) and is divided into occidental and oriental pears (10). P. pashia is small-to-medium in size and is a deciduous tree which prefers mainly moist soil. It can resist water scarcity and can survive well in surrounding air or water pollution (11). It is widely distributed and native to the Himalayan region from East Afghanistan, North Pakistan, Vietnam, the northern part of China, the Tang and Chockhor valley of the Bhumtang region in central Bhutan, the Indian north and eastern part up to $2.700 \mathrm{~m}$ above sea level (Fig. 1) and has also been introduced in Guinea. The inhabitants of the Khasi and Jaintia hills (Meghalaya, India) cultivate this plant in the tribal regions (12). Morphologically, it is a tall, thorny, open-headed tree with an average height of $9.7 \mathrm{~m}$. The leaves are 5-10 cm long, ovate- to broadly lance-shaped, long-pointed (with pointed tips), hairless and shiny.

The flowers of $P$. pashia mainly develop in FebruaryMarch with a diameter of $2.5-3 \mathrm{~cm}$ across, with epigynous white petals and darker veins. The fruit is round $(1.3-2.5 \mathrm{~cm})$, willow green at an immature stage, and turns black when fully matured with round brownish spots (Fig. 2). The endocarp contains grit cells. The fully ripe fruit yields a sweet and delightful flavor. It becomes fully mature during the period between May to December. The single fruit contains approximately five to six black-colored seeds. A mature tree can yield up to $45 \mathrm{~kg}$ of fruits per year. On average, the diameter of the $P$. pashia tree grows $30 \mathrm{~cm}$ in 8 years. The fruit taste varies from stringent to sweet and gritty (13). Sexual reproduction and vegetative reproduction are the standard means of reproduction in $P$. pashia fruit. The seeds stored under refrigerated conditions can remain viable for 2-3 years. The fruit and leaves are prone to scab infection. Therefore, if a scab comes into contact with the plant, it can rapidly spread, mainly through the root sprouts (14).

The validated taxonomic sources revealed that the accepted scientific name of the Kainth tree is $P$. pashia Buch.-Ham. ex D. Don belonging to the genus Pyrus $(15,16)$. Its various synonyms are Malus pashia Buch.-Ham. ex. Don, Pyrus variolosa Wall. ex G.Don, Pyrus verruculosa Bertol,
Pyrus pashia var. pashia, Pyrus nepalensis hort. ex Decne and Pyrus crenata D.Don. Some synonyms are still in use, although not entirely accepted, such as Aria crenata (D.Don) Decne, Cormus crenata (D.Don) Koehne and Sorbus variolosa (Wall. ex G.Don) S.Schauer (17). The taxon P.pashia Buch.-Ham. ex. D. Don is also listed in US National Plant Germplasm System (NPGS) with 38 species of Pyrus (18).

\section{Traditional uses of various parts of $\boldsymbol{P}$. pashia}

One of the most ancient known traditional medication systems is the Indian conventional medicine system containing maximum formulations from plants or plant extracts found in forest regions. The Ayurvedic, Unani, Siddha and tribal medicines use $>400$ plants, and $75 \%$ of plants are obtained from tropical forest areas and the remaining $25 \%$ from temperate forests (2). The medicinal formulation preparation from locally available plants remains an integral part of health care for individuals, mainly those residing in rural areas, where people cannot afford synthetic drugs due to their high cost (19). The wild fruit species can become the source of medications and economic growth to fulfill the nutritional and other desirable traits. In the Himalayan region, $P$. pashia is distributed with immense ethnic benefits and has been widely used by a number of local communities in the treatment of gastrointestinal, respiratory and vascular complications (2).

The local population has used the ripened fruits of $P$. pashia to treat constipation. Chettri et al reported that the wild edible fruits extract is beneficial for the treatment of ailments, such as dysentery. $P$. pashia fruit juice is astringent and has diuretic properties (20). Traditionally, the $P$. pashia fruit extract has been used in the treatment of eye conditions, digestive disorders (dyspepsia), headaches, sweating of the body (diaphoretic), hysteria, epilepsy, sore throat, irritability, anemia, abdominal pain, and has also been shown to be effective in the treatment of dysmenorrhea (21). Various processes, such as decoctions, infusion, maceration and percolation are used to extract biologically active compounds with medicine value (22). The decoction of dried fruits with other plant parts of $P$. pashia effectively improves spleen and stomach function. The fruits are also used as fodder for milk-producing animals to enhance their milk production (23). In the Yunnan Province of China, the flowers of P. pashia are consumed as a popular health food and have beneficial effects in lowering blood lipid levels. The decoction of flowers is also used to cure cough, emesis, and diarrhea (24). The leaves and twigs are bitter and serve as fodder for goats and sheep. The tribal communities also consume leaf decoction as a non-fermented health beverage (8).

The fresh leaves of $P$. pashia are known to possess properties, that are astringent, febrifuge, laxative and sedative in nature. The crushed leaves are also employed in cosmetics and are used toy color palms, feet and nails (25). Traditionally, the leaf extract is used as a tonic for hair loss treatments (26).

In the Ayurvedic system, the use of the bark and roots of $P$. pashia fruits is beneficial for the treatment of sore throat, fever, and peptic and gastric ulcers (27). The bark portion possesses astringent, laxative, anthelmintic and febrifuge properties, and is used as a tonic to cure typhoid fever (28). 


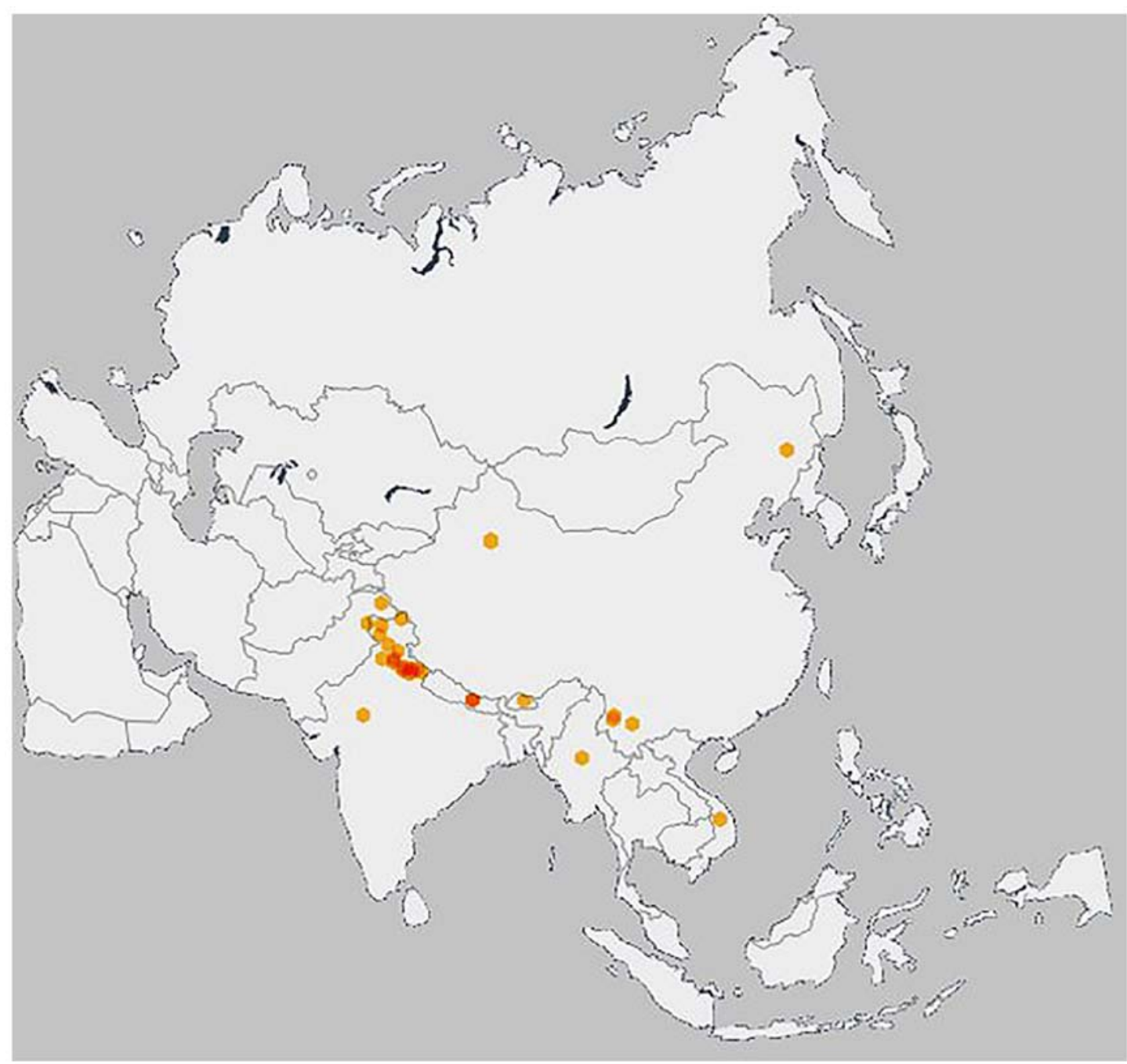

Figure 1. Distribution of Pyrus pashia Buch.-ham ex D. Don (55). On the mapk, orange dots indicate dense distribution and yellow dots indicate scanty distribution.

Some of the important traditional uses of the plant are listed in Table I.

The fruits are edible, and have religious and cultural significance. The fruits are rich in pigment contents, and may thus serve as an alternative to synthetic color. With the high demand for natural colors in the food-processing industries and strict laws for artificial colorants in numerous countries, the extracted dye from natural sources may be helpful for industrial purposes, with no adverse effects on the health of consumers (29). Apart from fruits and flowers, the wood of the P. pashia tree has been utilized in plywood making, tool handles and furniture construction. The seedlings of the $P$. pashia tree are used as rootstock for pear, apple and sweet cherry. Among the local population, there is the religious belief that keeping the twigs of P.pashia in the agricultural field can ward off evil spirits (30). Other diverse uses include the preparing of fencing, ropes, brooms, decorative articles and other household purposes by the inhabitants of the Lesser Himalayas (31).

\section{Nutritive value}

The ripened fruits of $P$. pashia have been reported to be nutritious and edible. Proximate analysis has demonstrated that the fruits contain $\sim 60.36 \pm 0.25$ moisture, $28.38 \pm 0.12 \%$ total carbohydrates, $6.79 \%$ reducing sugars, $16.18 \%$ crude fiber, $1.62 \pm 0.20 \%$ crude fat, $3.29 \pm 0.21 \%$ protein and $1.10 \pm 0.05$ of total ash content. These nutritional values of $P$. pashia indicate that it is a nutritionally rich fruit. The fruits contain various minerals, such as nitrogen $(0.68 \mathrm{mg})$, calcium $(0.75 \mathrm{mg})$, magnesium $(0.12 \mathrm{mg})$, potassium $(3.21 \mathrm{mg})$, phosphorus $(0.86 \mathrm{mg})$ and iron (traces) per $100 \mathrm{~g}$ dwb. The fruit is also rich in phytochemicals, such as gallic acid, chlorogenic acid and catechin $(32,33)$. To date, there are no published reports available regarding its vitamin contents, at least to the best of our knowledge. The fruit is still an underutilized source of nutrition due to its short shelf life and limited awareness.

Tag et al (34) studied the leaves of the P. pashia tree to determine its nutritional profile. The proximate analysis revealed that the leaves contained a low moisture content $(26.33 \pm 0.39 \%, \mathrm{dwb})$, ash $(4.40 \pm 0.19 \%, \mathrm{dwb})$, crude protein $(1.79 \pm 0.07 \%, \mathrm{dwb})$, crude fat $(0.89 \pm 0.07 \%, \mathrm{dwb})$, crude fiber $(21.22 \pm 1.18 \%, \mathrm{dwb})$ and a total carbohydrate content of $66.61 \pm 0.42 \%, \mathrm{dwb}$. The mineral content analysis revealed that the leaves contain low amount of sodium $(0.09 \%)$, phosphorus $(0.13 \%)$ and an ample amount of potassium $(0.80 \%)$ and calcium $(0.65 \%)$. The leaves were also found to contain a-tocopherol $(55.02 \pm 0.35 \mathrm{mg} / 100 \mathrm{~g})$ and carotenoids 


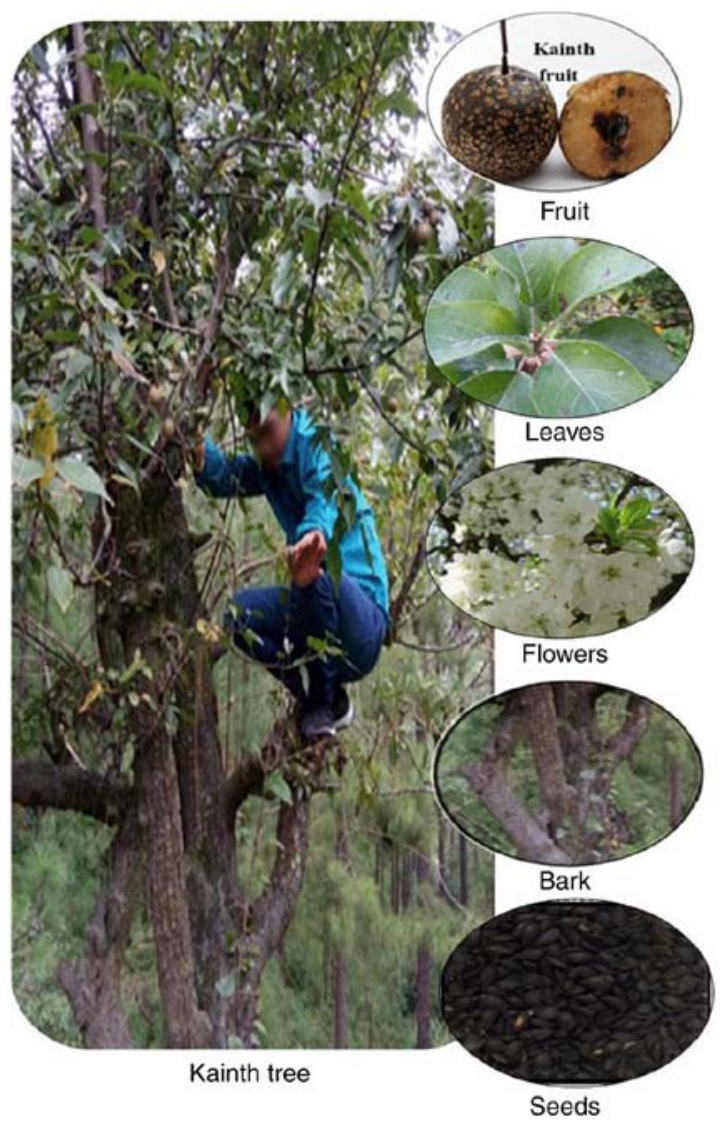

Figure 2. Different parts of Pyrus pashia Buch.-ham ex.D. Don (Kainth) (56).

$(0.083 \pm 0.001 \mathrm{mg} / 100 \mathrm{~g})(34)$. Taken together, the fruit and leaves have a proximate content, and the leaves contain a high amount of tocopherol, which can be utilized in the development of functional products.

\section{Phytochemistry and pharmacological properties}

Phytochemicals present in various parts of the P. pashia tree. The different parts of the P. pashia tree exhibit various beneficial phytochemicals (Tables II and III) with a wide range of biological activities. Alkaloids, glycosides, saponins, steroids, phenols, flavonoids, tannins, proteins and essential amino acids have been found in the P. pashia bark portion (30). He et al investigated the chemical constituents of P. pashia flower and isolated 28 compounds (35). They also reported a novel glycosidic phenolic compound, namely 4-O-Z-coumaroyl-arbutin, along with other 27 already published compounds (Table II). Among the 28 compounds, hydroquinone exhibited the highest content $(10.31 \pm 0.21 \mathrm{mg} / \mathrm{g} \mathrm{dwb})$. This potent antioxidant level offers a vital role in the overall antioxidant potential of $P$. pashia flowers. The other significant phytochemicals identified were kaempferol 3-rutinoside $(6.22 \pm 0.0 .23 \mathrm{mg} / \mathrm{g} \mathrm{dwb})$ and arbutin

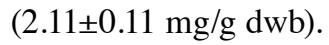

In the branches and leaves, 20 terpenoids and two new terpenoids have been reported (36). The structure elucidation of these terpenoids was carried out using spectroscopic [infrared (IR), high resolution electrospray ionization mass spectrometry (HRESIMS), one and two-dimensional nuclear magnetic resonance (NMR)] and chemical analysis. The assigned structures were $2 \alpha, 3 \beta, 27$-trihydroxyolean-12-en-28-oic acid and $(4 \alpha)$-3-(5, 5-dimethyl tetra hydro furanyl)-1-buten-3-ol 3-O- $\beta$-D-glucopyranoside. In another study, Li et al (37) isolated two new cyclic hexapeptides from the branches and leaves of the P. pashia tree. The two compounds, pashinintide A (cyclic hexapeptide, with a saccharose) and pashinintide B (cyclic heptapeptide), were identified based on NMR (one and two-dimensional ${ }^{1} \mathrm{H},{ }^{13} \mathrm{C}$ NMR) spectroscopy and HRE-IMS/HRESIMS. That study suggested that pashinintide A [cyclo (-Ala ${ }^{1}-\mathrm{Gly}^{2}-\mathrm{Pro}^{3}-\mathrm{Gly}^{4}-\mathrm{Trp}^{5}-\mathrm{Pro}^{6}-$ )] can act as a natural receptor for saccharides. The n-butanol extract of leaves exhibited the presence of amburoside A (4-O-b-D-glucopyranosyl benzyl-benzoate ester), an unknown bioactive substance, and 21 known phenolics (37). Among the 22 compounds identified, 3,5-dicaffeoyl quinic acid and methyl 3,5-dicaffeoylquinate exhibited the highest antioxidant activities $\left(\mathrm{IC}_{50}, 13.26 \pm 0.04\right.$ and $13.28 \pm 0.11 \mu \mathrm{M}$, respectively), which may be due to the caffeoyl group present in these compounds.

Phytochemical and pharmacological investigations on the $P$. pashia fruit have revealed secondary metabolites, such as alkaloids, flavonoids, steroids, tannins, lupeol, $\beta$-sitosterol, $\beta$-sitosterol- $\beta$-D-glucoside, and also possess antimicrobial activity (7). A previous study demonstrated that the $P$. pashia fruit comprised of major phenolics, such as gallic acid, catechin, caffeic acid, coumaric acid, ellagic acid and several other phytochemicals (33). A previous study by the authors also demonstrated 28 phenolic compounds in the fractionated (free, esterified, and bound form) ethanolic extract of Kainth fruits (38). Arbutin, chlorogenic acid, catechin, epicatechin and procyanidin $\mathrm{B}_{2}$ were the major phenolic compounds identified using LC-HRMS/MS (38).

Phenolic content and antioxidant level of major phytochemicals. The different parts of the $P$. pashia tree are a rich source of various polyphenols, attracting attention due to the redox potential that allows them to function as reducing agents, hydrogen donors, singlet oxygen quenchers, or metal chelators (39). Various studies have been carried out for the isolation, identification and quantification of phenolics. Siddiqui et al (40) demonstrated the sequential extraction of phytochemicals from various parts of the P. pashia tree using several solvents, such as methanol, hexane, chloroform, ethyl acetate, n-butanol and aqueous extract. Analyses of multiple antioxidant activities were carried out for the aforementioned phenolic extracts, and ethyl acetate exhibited optimal results. The ethyl acetate extract of the bark, fruit and leaves exhibited the highest phenolic content of $393.19 \pm 0.72,237.32 \pm 0.89$ and $321.23 \pm 0.74 \mathrm{mg}$ per $100 \mathrm{~g}$, respectively. The ethyl acetate extract also exhibited the highest antioxidant level for the bark, fruit and leaf portion (40).

He et al (35) examined the effect of the crude ethanolic extract of $P$. pashia flowers and soluble fractions on cell membrane lipid peroxidation (Table IV). The extract was shown to inhibit lipid peroxidation in mouse liver and kidney tissues at a dose of $20 \mu \mathrm{g} / \mathrm{ml}$. That study validated the therapeutic potential of P. pashia flowers in Chinese medicine (35).

Rawat et al (41) also estimated the total phenolics and flavonoid content in bark and leaves of P. pashia. The total 
Table I. Traditional uses of Pyrus pashia Buch.-Ham. ex D.Don (Kainth).

\begin{tabular}{|c|c|c|c|}
\hline Serial no. & Plant parts & Uses & (Refs.) \\
\hline \multirow[t]{10}{*}{1} & \multirow[t]{10}{*}{ Fruit } & Tribal populations use it in their diet; useful for combatting constipation & $(49)$ \\
\hline & & Minimize thirst & $(49)$ \\
\hline & & Fruit juice is astringent and diuretic & $(49)$ \\
\hline & & Managing dysentery & $(49)$ \\
\hline & & Helpful in leishmaniasis, eye problems, sedative & $(7)$ \\
\hline & & Useful in the treatment of dyspepsia and dysmenorrhea & (7) \\
\hline & & Digestive disorders, sore throat, irritability & $(49)$ \\
\hline & & Abdominal pain, anemia & $(44)$ \\
\hline & & Decoction of dried fruits helps to improve spleen and stomach functions & (49) \\
\hline & & Added in cattle fodder to enhance milk production & $(23)$ \\
\hline \multirow[t]{5}{*}{2} & \multirow[t]{5}{*}{ Leaves and Branches } & Serve as fodder for goats and sheep & $(49)$ \\
\hline & & Leaf extract used as non-fermented beverage & $(8)$ \\
\hline & & Improve cosmetic appearance & $(8)$ \\
\hline & & Cure abdominal pain and diarrhea in Chinese folk medicine & $(8)$ \\
\hline & & Tonic for hair loss & (49) \\
\hline \multirow[t]{2}{*}{3} & \multirow[t]{2}{*}{ Flower } & Used as a health food to lower blood lipid in the Yunnan province of China & (24) \\
\hline & & Treatment of cough, emesis and diarrhea & (24) \\
\hline \multirow[t]{3}{*}{4} & \multirow[t]{3}{*}{ Bark } & Possesses astringent and tonic properties & $(49)$ \\
\hline & & Used in the management of sore throat, fever, and peptic and gastric ulcers & $(49)$ \\
\hline & & Useful for treating typhoid fever & $(49)$ \\
\hline
\end{tabular}

phenolic and total flavonoids in the bark and leaf portion were found to be $98 \pm 05$ and $325 \pm 10 \mathrm{mg}$ gallic acid equivalent and $10.30 \pm 10$ and $150 \pm 20 \mathrm{mg}$ quercetin equivalent per gram of extract powder, respectively (41). A previous study demonstrated the total phenolics and the free radical scavenging level of methanol and water extracts of leaves; the methanolic leaf extract was shown to have the highest phenolic content (351.16 $\pm 0.43 \mathrm{mg} / \mathrm{g}$ extract) (8). Li et al (37) also demonstrated that the butanol extract of the bark and leaves possessed a high antioxidant level. Overall, the aforementioned studies highlighted the antioxidants level of various plant parts of $P$. pashia and broadened their applications to prevent degenerative diseases. Extensive research is required however to analyze the role of different classes of compounds present, which may lead to the more beneficial use of the plant in society.

Pharmacological properties. The various pharmacological activities of different plant portions may be due to phenolics, flavonoids, alkaloids, tannins and terpenoids.

Antimicrobial activity. Medicinal plants, rich in various phytochemicals, may serve as potent antimicrobials. In a number of countries, wildly grown plants are used for medicinal purposes (42). The various extracts from $P$. pashia plant parts have exhibited antimicrobial activities against pathogenic bacteria and fungi. The ethanolic extract of the fruit skin has exhibited significant antibacterial activity against Klebsiella pneumonia, Shigella flexneri and Escherichia coli. Furthermore, the chloroform and ethanolic extracts of fruits have been shown to exhibit potent antifungal activity against Candida albicans, Aspergillus flavus and Aspergillus parasiticus at a $50 \mathrm{mg} / \mathrm{ml}$ concentration (Table IV) (33).
Anti-inflammatory and antiproliferative activities. It is known that a diet rich in fruits and vegetables, primarily due to the contribution of natural polyphenols, can reduce the incidence of specific cancers. The consumption of phenolic-rich fruits and other plant parts is related to anti-inflammatory activity and a reduced the risk of certain types of cancer and cardiovascular diseases (43). Chandra et al (44) demonstrated the anti-inflammatory activity of the methanolic extract of P.pashia. They found that the oral gavage of methanolic extract at a level of 100 and $150 \mathrm{mg} / \mathrm{kg}$ body weight in adult albino rats of either sex reduced the volume of carrageenan-induced inflammation by 56.6 and $61.12 \%$, respectively (44). This anti-inflammatory effect may be due to the presence of flavonoids, terpenoids and phenolic compounds. However, Chandra et al (44) were not able to identify the compound responsible for the anti-inflammatort effect.

In another study, the methanolic extract of the $P$. pashia leaves was found to exert an anti-inflammatory effect at sublethal doses of $50-150 \mathrm{mg} / \mathrm{ml}$; the methanolic extract with the highest dose $(150 \mathrm{mg} / \mathrm{ml})$ was equally effective as a standard drug (indomethacin) (45). The triterpenoids present in branches and leaves have also been shown to exhibit anti-inflammatory properties (46).

Saini et al (39) also studied the anti-proliferative potential of methanol and acetone extracts $(0.667-6.67 \mathrm{mg} / \mathrm{ml})$ of $P$. pashia fruit against two human cervical cancer cell lines $(\mathrm{C} 33 \mathrm{~A}$ and HeLa cell lines). Both the extracts exhibited anticancer activities $\left(\mathrm{IC}_{50}-13.97\right.$ and $\left.10.72 \mathrm{mg} / \mathrm{ml}\right)$ for the methanol and acetone extracts, respectively (39). Saini et al (39) also demonstrated a high amount of gallic acid, caffeic acid, catechin and ellagic acid traces. The high antiproliferative activity may be due to high phenolic and flavonoid content and ellagic content (47). Li et al (37) also demonstrated the cytotoxicity of terpenoids 
Table II. Phytochemicals reported from Pyrus pashia Buch.-Ham. ex D.Don (Kainth).

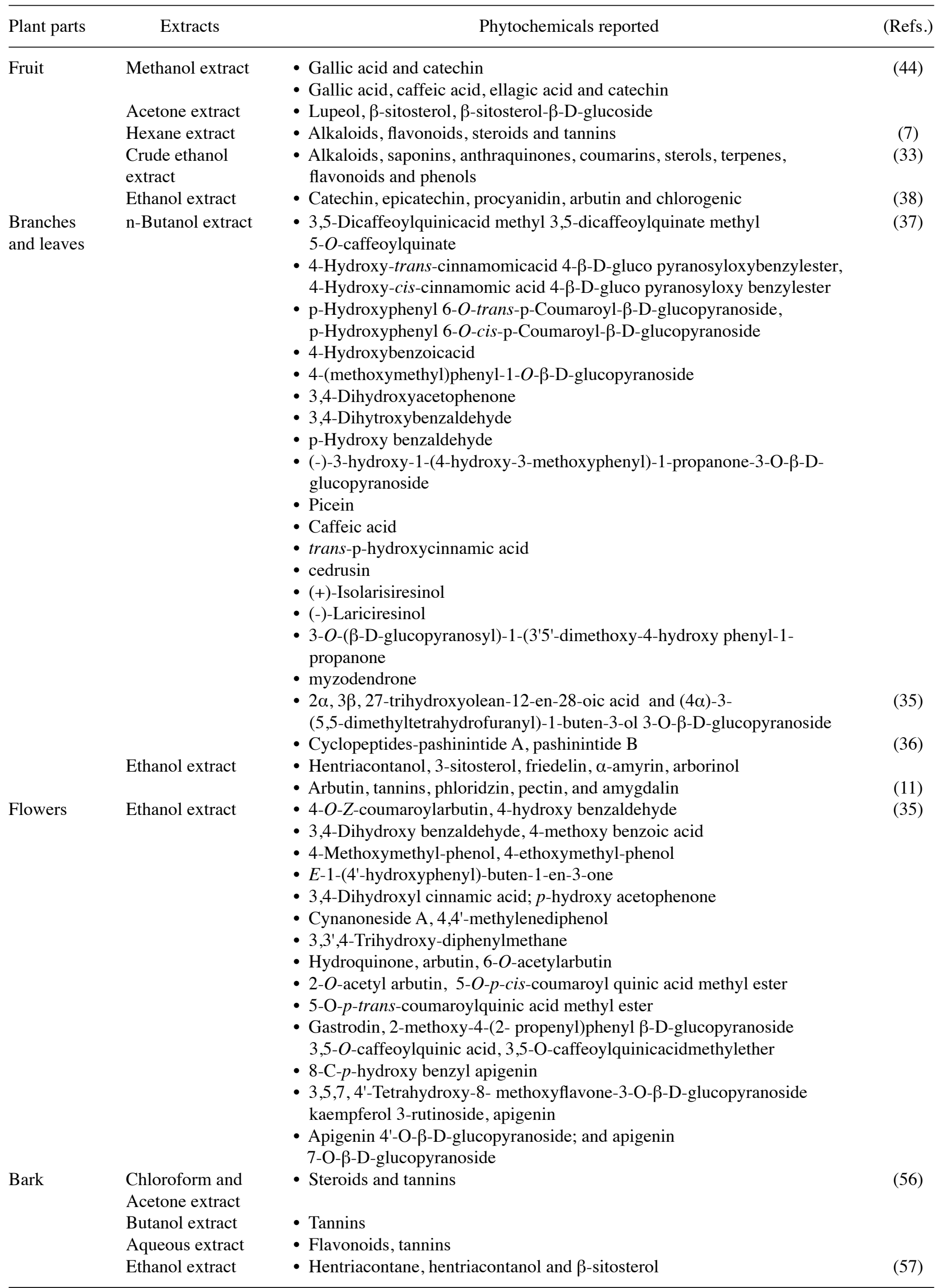




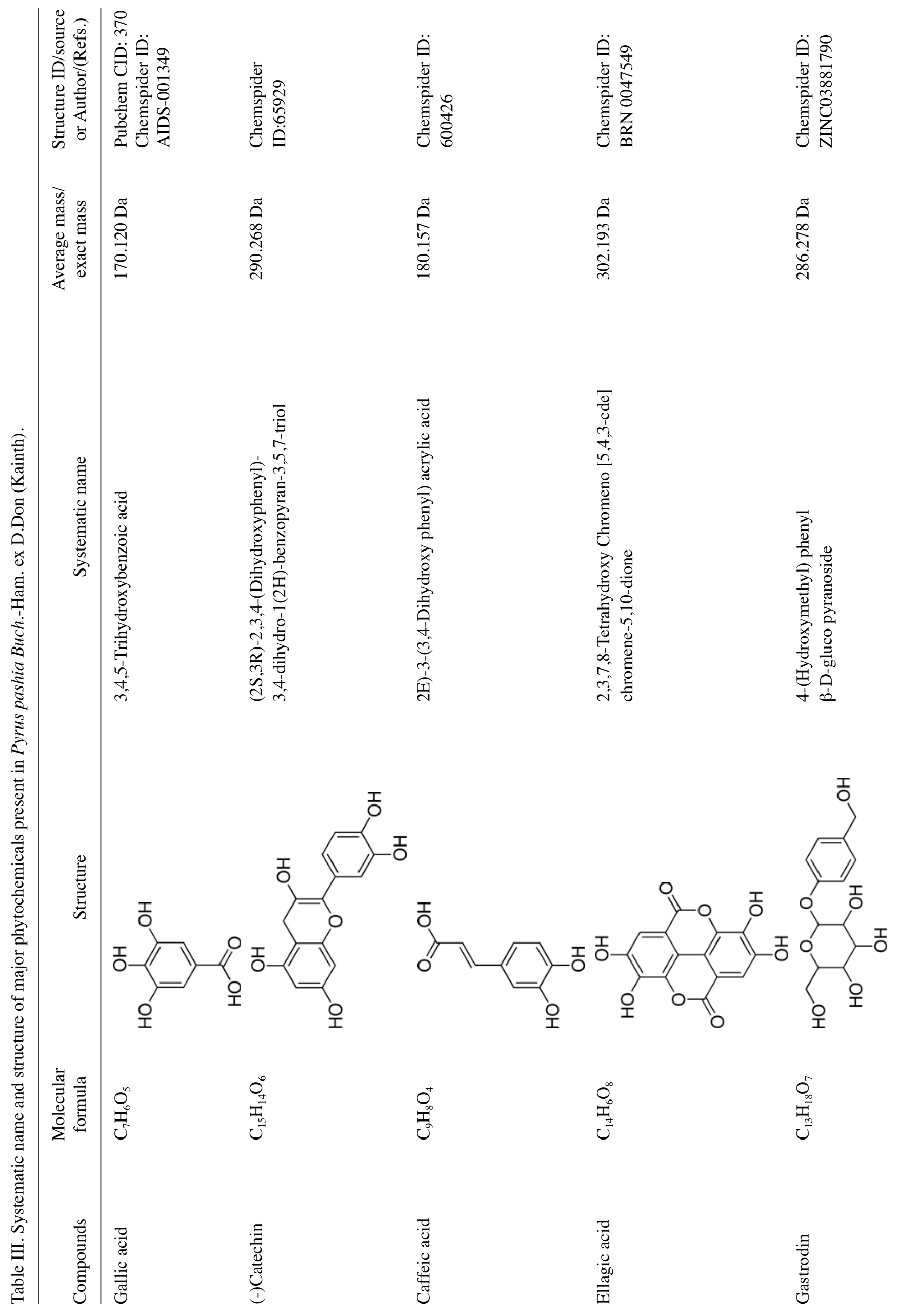




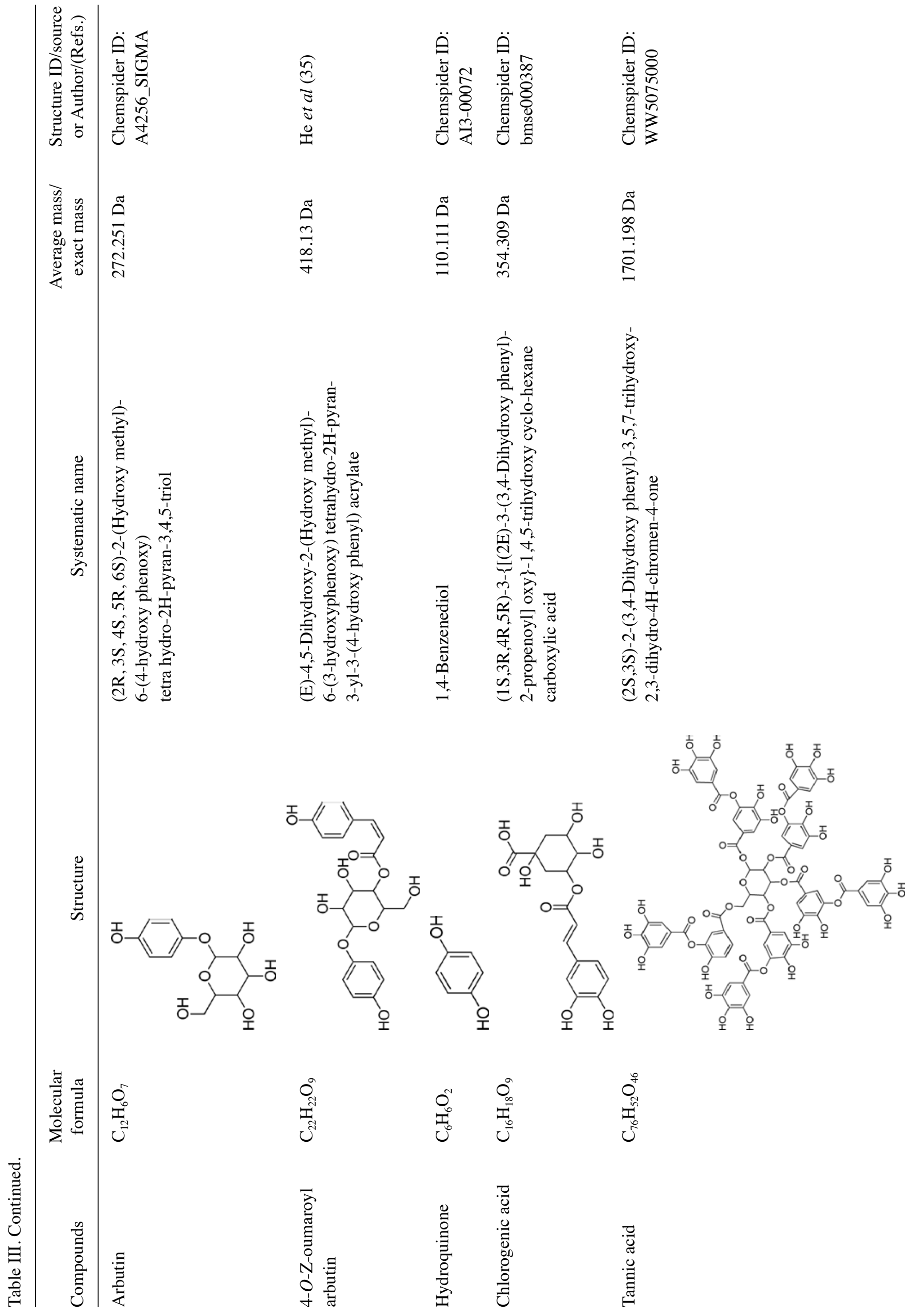




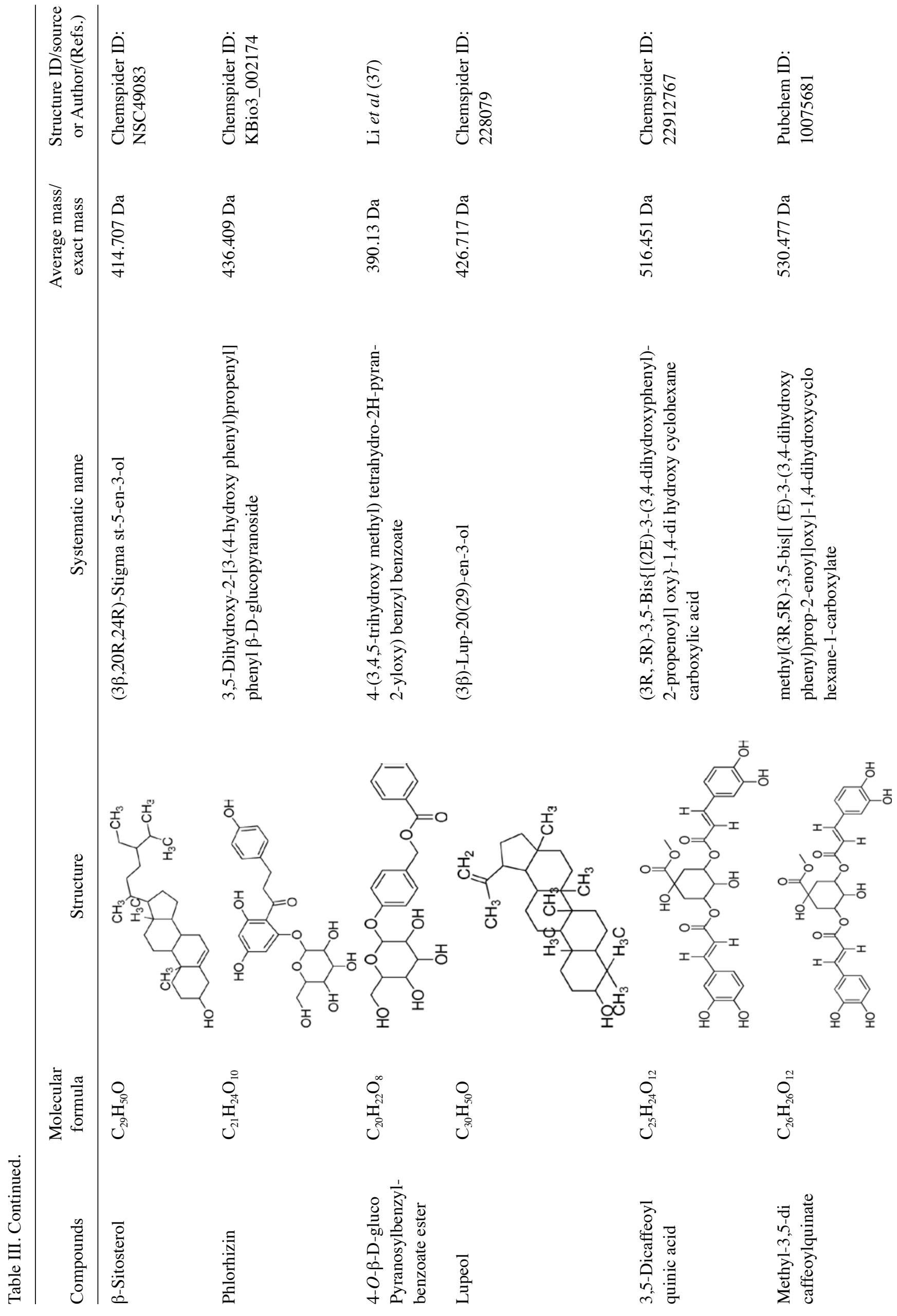




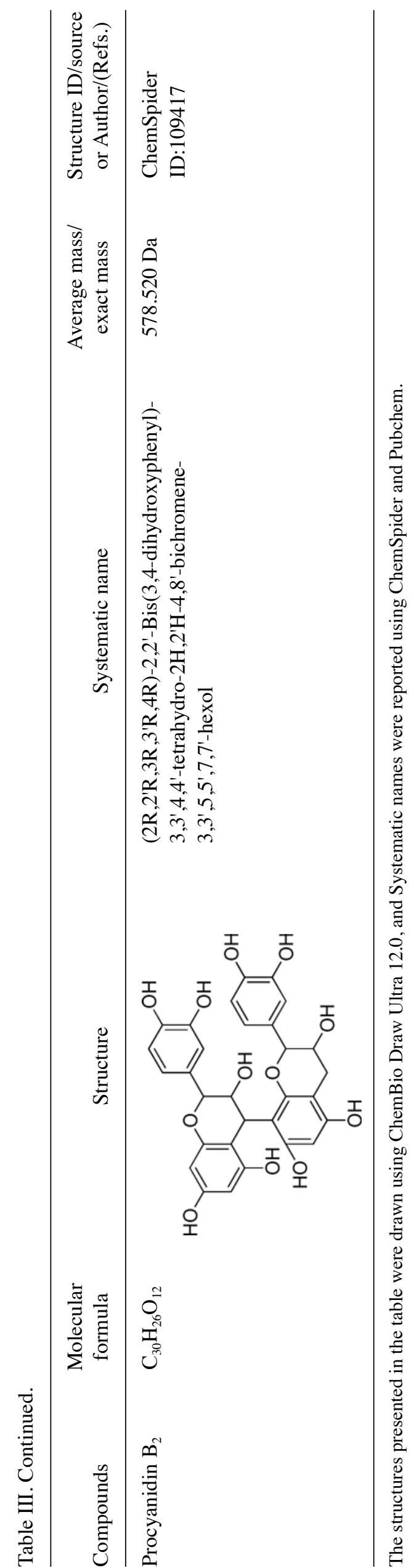

from the leaves and branches of $P$. pashia against cancer cell lines. Among the 22 compounds reported previously in the branches and leaves, two compounds exhibited anticancer activities. The terpenoids 3-O-(E)-p-coumaroyltormentic

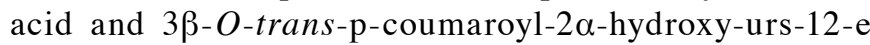
n-28-oic acid exhibited significant cytotoxic effects. The compound 3-O-(E)-p-coumaroyltormentic acid exhibited cytotoxic activities against the A549 ( $\left.\mathrm{IC}_{50} 19.18 \pm 4.26 \mathrm{mM}\right)$, HeLa $\left(\mathrm{IC}_{50} 12.56 \pm 3.89 \mathrm{mM}\right), \mathrm{SGC} 7901\left(\mathrm{IC}_{50} 10.48 \pm 1.95 \mathrm{mM}\right)$ and NHI-1975 $\left(\mathrm{IC}_{50} 7.38 \pm 2.31 \mathrm{mM}\right)$ cell lines. However, the compound 3 $\beta$-O-trans-p-coumaroyl-2 $\alpha$-hydroxy-urs-12-en -28-oic acid displayed cytotoxic activities against the A549 $\left(\mathrm{IC}_{50} 14.71 \pm 1.47 \mathrm{mM}\right.$ ) and HeLa ( $\left.\mathrm{IC}_{50} 12.22 \pm 1.88 \mathrm{mM}\right)$ cell lines $(36,37)$. The aforementioned studies indicate that $P$. pashia extract has various traditional uses, such as in the treatment of typhoid fever, pain relief and cough, as well as for the treatment of other inflammatory diseases.

Hepatoprotective activity. The aqueous extract of $P$. pashia leaves have been shown to exhibit hepatoprotective activity against carbon tetrachloride $\left(\mathrm{CCl}_{4}\right)$-induced liver damage (48). It has been show that pre and post-treatment with the aqueous extract of the leaves led to a significant reduction in the serum level of enzymes (serum transaminase, phosphatase and bilirubin) and total protein content compared with the $\mathrm{CCl}_{4}$-treated groups (48). Thus, the leaf extracts can be utilized in the pharmaceutical and food industry due to their richness in phenolics and flavonoids.

Spasmolytic, bronchodilator and vasoconstrictive activities and amelioration of convulsions. Traditionally, P. pashia fruits are utilized in the treatment of gastrointestinal, respiratory and vascular complications. A previous study validated the scientific reason behind the use of $P$. pashia fruit in the traditional medicine system (49). It was demonstrated that the aqueous ethanolic extract $(10 \mathrm{mg} / \mathrm{ml})$ of $P$. pashia fruit exhibited spasmolytic, bronchodilator and vasoconstrictive activities. They also reported that the blockage of $\mathrm{Ca}^{2+}$ ion channels in the presence of phytochemicals (alkaloids, flavonoids, glycosides and anthraquinones) may be a possible mechanism of the spasmolytic and bronchodilator activities of the extract. Additionally, the vasoconstrictive properties may be due to the $\alpha$-adrenergic, muscarinic, serotonergic and angiotensin II combative components present in the $P$. pashia extract (49).

The ethanolic extract of the fruit of $P$. pashia has been shown to exhibit significant anticonvulsant activity (50). Furthermore, chrysin extracted from ethanolic $P$. pashia extract has also been shown to exhibit substantial anticonvulsant activity at a $2.5-10 \mathrm{mg} / \mathrm{kg}$ BW concentration in a rat model against pentylenetetrazole (PTZ)-induced convulsions (50).

Overall, the various biofunctional activities in the extracts of different plant parts of P. pashia may be due to the presence of phenolics and flavonoids, individually or synergistically.

Cytotoxicity and toxicological studies. The study of the acute toxicity of hydroethanolic extracts tested at doses of 200 and $400 \mathrm{mg} / \mathrm{kg}$ has revealed no cytotoxicity up to $72 \mathrm{~h}$ and has been found to be safe up to $1 \mathrm{~g} / \mathrm{kg}$ body weight in female albino mice (51). The extract has been shown to exert 


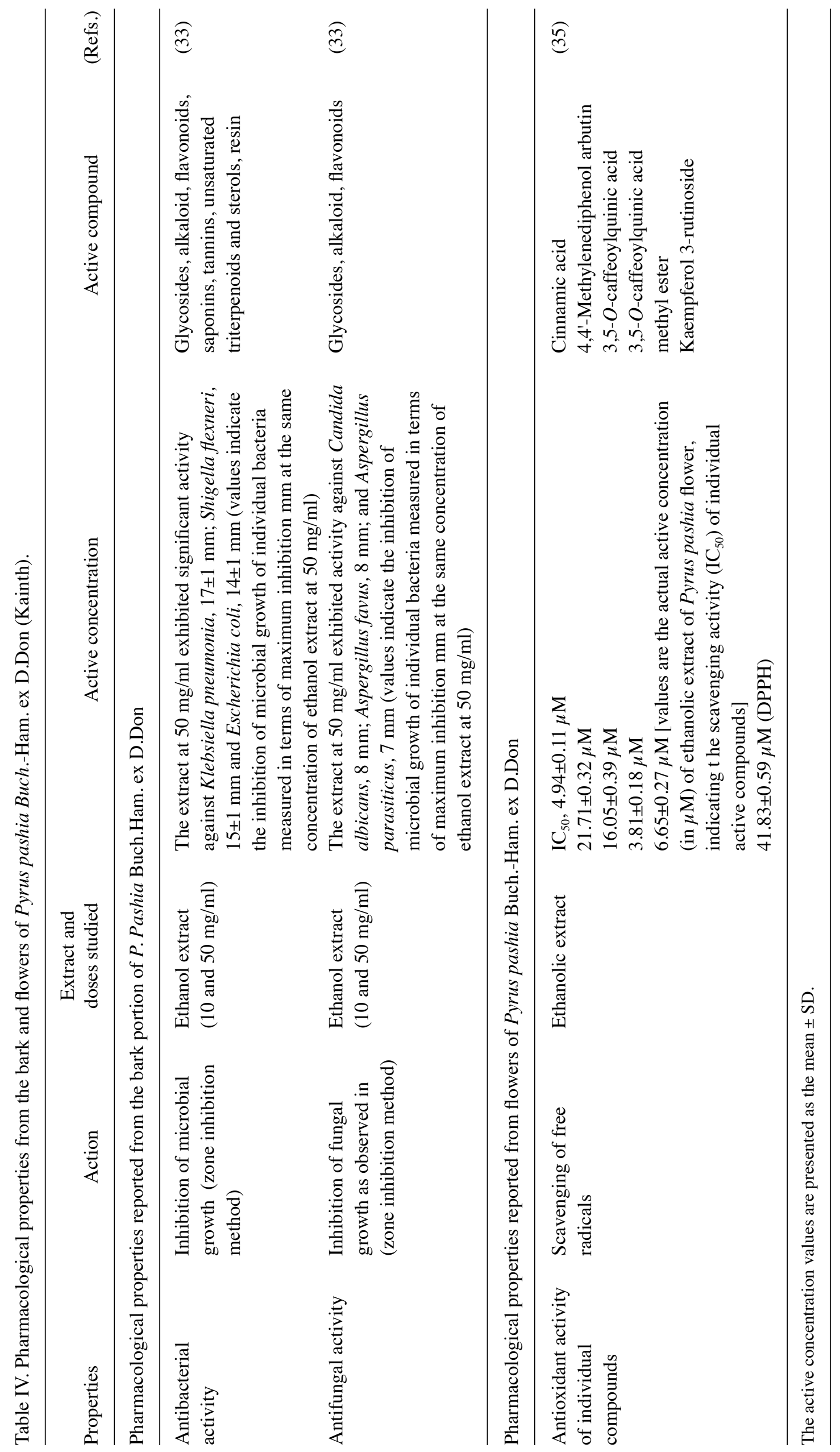


a sedative-hypnotic effect at the concentration of $\geq 400 \mathrm{mg} / \mathrm{kg}$ body weight, although cytotoxicity was observed only at the concentration of $1,500 \mathrm{mg} / \mathrm{kg}$ body weight (51). The outcome of that study may lead to the development of treatment strategies for conditions such as insomnia, providing a scientific rationale for its ethnomedicinal use.

Another study demonstrated that toxic metals could promote metabolic disorders, such as harmful effects on the gut microbiota and the development of diseases, such as obesity, type 2 diabetes mellitus, metabolic diseases and cancer (52). P. pashia fruit also contains toxic metals such as cadmium, zinc, nickel, lead and mercury, although within the recommended limits (53). Therefore, various plant parts of $P$. pashia can be utilized in medicinal formulations for the treatment of multiple diseases without the possibility of metal poisoning. In a previous study, no notable cytotoxicity against peripheral blood mononuclear cells was observed in a concentration $<6.67 \mathrm{mg} / \mathrm{ml}$ (39). The hydroquinone present in $P$. pashia flowers $(10.3 \pm 0.2 \mathrm{mg} / \mathrm{g} \mathrm{dwb})$ has been shown to exhibit assured toxicity (9). It has also been demonstrated that hydroquinone exhibits acute toxicity via the oral and dermal routes of exposure with median lethal dose $\left(\mathrm{LD}_{50}\right)$ values of $70 \mathrm{mg} / \mathrm{kg} \mathrm{BW}$ in cats to $550 \mathrm{mg} / \mathrm{kg}$ BW in guinea pigs (54), thus suggesting that their moderate consumption is feasible. Thus, $P$. pashia flowers may be a natural source of antioxidants with potential applications in functional foods.

\section{Conclusion and future perspectives}

Various parts of the $P$. pashia tree have long been used traditionally in the Indian medicinal system, particularly in the Himalayan region. The fruit is edible and represents a source of high nutritional value. Various phytochemicals have been reported in the fruit, flower, leaves and bark portion of th plant. However, research on $P$. pashia for pharmacological properties is minimal due to the limited information available regarding different plant parts. To date, and to the best of our knowledge, there are no clinical trial reports available on this plant species. There is a scope to study the potential of these phytochemicals at the gene level responsible for particular biological activity. The various phytochemicals reported from the fruit, flower, bark and leaves may be used to develop a novel drug by using the reverse pharmacological approach to curing various diseases.

The present review provides a scientific basis for the utilization of $P$. pashia for the discovery and development of innovative approaches in therapeutics, for the development of nutraceuticals and to enhance the quality of functional foods. Therefore, intense efforts are required to explore its unlimited pharmacological properties and to create awareness among the population as to its benefits so as to effectively use the constituents of the plant.

\section{Acknowledgements}

The authors are grateful to Dr Sridevi Annapurna Singh, Director of CSIR-Central Food Technological Research Institute, Mysuru, India, for her keen interest and constant encouragement regarding the present study.

\section{Funding}

The present received financial support from the University Grant Commission, New Delhi, as a Junior Research Fellowship (NFO-OBC-JRF-2014-15).

\section{Availability of data and materials}

Not applicable.

\section{Authors' contributions}

OP was involved in the design of the study and in the literature search and selection of the data/information to be included. ASC was involved in the design of the study. VBK was involved in the conception of the study. OP and VBK confirm the authenticity of all the raw data. All authors have read and approved the final manuscript.

\section{Ethics approval and consent to participate}

Not applicable.

\section{Patient consent for publication}

Not applicable.

\section{Competing interests}

The authors declare that they have no competing interests.

\section{References}

1. Ved DK and Goraya GS: Demand and Supply of Medicinal Plants in India. 1st edition. Foundation for Revitalisation of Local Health Traditions. National Medicinal Plants Board, New Delhi, 2008.

2. Kumar M, Sheikh MA and Bussmann RW: Ethnomedicinal and ecological status of plants in Garhwal Himalaya, India. J Ethnobiol Ethnomed 7: 32, 2011.

3. Pandey A and Negi PS: Traditional uses, phytochemistry, and pharmacological properties of Neolamarckia cadamba: A review. J Ethnopharmacol 181: 118-135, 2016.

4. Matin A, Khan MA, Ashraf M and Qureshi RA: Traditional use of herbs, shrubs, and trees of Shogran valley, Mansehra. Pak J Bio Sci 4: 1101-1107, 2001.

5. Ahmad Z: Country Report on Plant Genetic Resources for Food and Agriculture-Pakistan. National Agricultural Research Centre, Islamabad, Pakistan, p79, 2007.

6. Ghora C and Panigrahi G: The family Rosaceae in India. In: Revisionary Studies on Six Genera (Prunus, Prinsepia, Maddenia, Rosa, Malus, and Pyrus). Vol 2. Bishen Singh Mahendra Pal Singh, Dehradun, p481, 1995.

7. Khandelwal R, Paliwal S, Chauhan R and Siddiqui A: Phytochemical screening of hexane soluble fraction of Pyrus pashia fruits. Oriental J Chem 24: 773-774, 2008.

8. Tsering J, Gogoi BJ and Tag H: Ethnobotany and phytochemical analysis of Pyrus pashia leaves. Int J Pharm Sci Res 3: 2721-2725, 2012.

9. Liu CS, Tai ZG, Liu Y, Ma YC, Cai L and Ding ZT: Chemical constituents of the flowers of Pyrus pashia Buch.-Ham. ex. D.Don. Lish Med Mater Med Res 22: 2373-2375, 2013.

10. Bailey LH: Pyrus. In: Standard Cyclopedia of Horticulture, Macmillan, New York, NY, pp2865-2878, 1997.

11. Arya V, Gupta R and Gupta VK: Pharmacognostic and phytochemical investigations on Pyrus pashia Buch.-Ham. Ex D. Don stem bark. J Chem Pharm Res 3: 447-456, 2011.

12. Hanelt P (ed): The Mansfield's Encyclopedia of Agricultural and Horticultural Crops. Institute of Plant Genetics and Crop Plant Research (IPK). Vol 6. Springer, Berlin, 2001. 
13. Parmar C and Kaushal MK: Pyrus pashia. In: Wild Fruits. Kalyani Publishers, New Delhi, pp78-80, 1982.

14. Sheikh MI: Trees of Pakistan. Vol 110. Pictorial Printers, Islamabad, 1993.

15. Medicinal Plant Names Services - Kew Gardens. Available from: https://www.kew.org/science/our-science/science-services/ medicinal-plant-names-services. Accessed July, 29, 2020.

16. Plants of the world online. Available from: http://www.plantsoftheworldonline.org/taxon/urn:lsid:ipni.org:names:731109-1\#distri bution-map. Accessed, July 29, 2020.

17. Theplantlist,2013: Version 1.1.Published on the Internet. Available from: http://www.theplantlist.org/tp11.1/record/rjp-2161. Accessed, November 27, 2020.

18. Postman JD: World Pyrus Collection at USDA Genebank in Corvallis, Oregon. In X International Pear Symposium 800, pp527-534, 2007.

19. Verma AK, Kumar M and Bussmann RW: Medicinal plants in an urban environment: The medicinal flora of Banaras Hindu University, Varanasi, Uttar Pradesh. J Ethnobiol Ethnomed 3: 35 , 2007.

20. Chettri N, Sharma E and Lama SD: Non-timber forest produces utilization, distribution, and status in a trekking corridor of Sikkim, India. Lyonia 8: 89-101, 2005.

21. Murad W, Ahmad A, Gilani SA and Khan MA: Indigenous knowledge and folk use of medicinal plants by the tribal communities of Hazar Nao Forest, Malakand District, North Pakistan. J Med Plants Res 5: 1072-1086, 2011.

22. Devgan M, Bhatia L and Kumar H: Anthocephalus cadamba: A comprehensive review. Res J Pharm Technol 5: 1478-1483, 2012.

23. Jiangsu New Medical College: 'Dictionary of Chinese Traditional Medicine'. Shanghai People's Press, 1986.

24. Cai L, Zhao M, Liu S, Yin T, Zhou H, Dong J, Yang Y and Ding Z: Pashinintide A, the first plant cyclopeptide from Rosaceae, included a sucrose, suggests a new natural receptor for saccharide. Tetrahedron Lett 55: 6231-6235, 2014.

25. Shinwari MI and Khan MA: Multiple dimensions of ethnobotany and its present status in Pakistan. Hamdard Med 42: 5-10, 1998.

26. Gulia KS: Human ecology of Sikkim: A case study of Upper Rangit Basin. Gyan Publishing House, Delhi, India, pp225, 2005.

27. Manandhar NP: A survey of medicinal plants of Jajarkot district, Nepal. J Ethnopharm 48: 1-6, 1995.

28. Kala CP: Medicinal Plants of Indian Trans-Himalaya: Focus on Tibetan Use of Medicinal Resources. Bishen Singh Mahendra Pal Singh, Dehradun, pp200, 2002.

29. Rymbai H, Roy AR, Deshmukh NA, Jha AK, Shimray W, War GF and Ngachan SV: Analysis study on potential underutilized edible fruit genetic resources of the foothills track of Eastern Himalayas, India. Genet Resour Crop Evol 63: 125-139, 2016.

30. Arya D: Plant species used as traditional agricultural implements and tools in Garwhal region of western Himalaya. Ind J Sci Res and Tech 2: 69-72, 2014.

31. Abbasi AM, Khan MA, Khan N and Shah MH: Ethnobotanical survey of medicinally important wild edible fruit species used by tribal communities of Lesser Himalayas-Pakistan. J Ethnopharmacol 148: 528-536, 2013.

32. Saha D, Sundriyal M and Sundriyal RC: Diversity of food composition and nutritive analysis of edible wild plants in a multi-ethnic tribal land, Northeast India: An important facet for food supply. Indian J Tradit Know 13: 698-705, 2014.

33. Saklani $S$ and Chandra S: In vitro antimicrobial activity, nutritional profile of medicinal plant of Garhwal, Himalaya. Int J Pharm Sci Res 3: 268-272, 2012.

34. Tag H, Tsering J, Hui PK, Gogoi BJ and Veer V: Nutritional potential and traditional uses of high altitude wild edible plants in the eastern Himalayas, India. IJABE 8: 226-231, 2014.

35. He J, Yin T, Chen Y, Cai L, Tai Z, Li Z, Liu C, Wang Y and Ding Z: Phenolic compounds and antioxidant activities of edible flowers of Pyrus pashia. J Funct Foods 17: 371-379, 2015

36. Lia ZJ, Wan CP, Cai L, Li SQ, Zheng X, Qi Y, Dong JW, Yin TP Zhou ZX, Tan NH and Ding ZT: Terpenoids with cytotoxic activity from the branches and leaves of Pyrus pashia. Phytochem Lett 13: 246-251, 2015.

37. Li ZJ,Zheng X, Wan CP, Cai L, Li Y, Huang L and Ding ZT: A new phenolic compound with antioxidant activity from the branches and leaves of Pyrus pashia. Nat Prod Res 30: 1136-1143, 2016.
38. Prakash O Baskaran R and Kudachikar VB: Characterization, quantification of free, esterified and bound phenolics in Kainth (Pyrus pashia Buch.-Ham. Ex D.Don) fruit pulp by UPLC-ESI-HRMS/MS and evaluation of their antioxidant activity. Food Chem 299: 125114, 2019.

39. Saini R, Garg V and Dangwal K: Comparative study of three wild edible fruits of Uttrakhand for antioxidant, antiproliferative activities and polyphenolic composition. Int J Pharm Sci Res 3: 158-167, 2012.

40. Siddiqui SZ, Ali S, Rubab K, Abbasi MA, Ajaib M and RasoolZG: Pyrus pashia: A persuasive source of natural antioxidants. Pak J Pharm Sci 28: 1763-1772, 2015.

41. Rawat P, Saroj N, Rawat P, Kumar P, Singh TD and Pal M: Evaluation for Total Phenolic, Total Flavonoid, and Antioxidant activity of leaves and roots of Pyrus pashia. Int J Med Pharm Res 1: 193-196, 2015.

42. Srivastava JP, Lambert J and Vietmeyer N: Medicinal plants: An expanding role in development. The World Bank-Technical Papers., pp320, 1996.

43. Oliveras-López MJ, Berná G, Jurado-Ruiz E, De La Serrana HL and Martín F: Consumption of extra-virgin olive oil rich in phenolic compounds have beneficial antioxidant effects in healthy human adults. J Funct Foods 10: 475-484, 2014

44. Chandra S, Saklani S and Kumar S: In-vivo Anti-inflammatory activity of Pyrus pashia fruit. World J Pharm Sci 4: 273-276, 2016.

45. Pandey N, Singh A and Pant J: In-vivo anti-inflammatory activity of methanolic extract of leaves part of Pyrus pashia. WJPR 6: 621-628, 2017.

46. Yan M, Zhu Y, Zhang HJ, Jiao WH, Han BN, Liu ZX, Qiu F, Chen WS and Lin HW: Anti-inflammatory secondary metabolites from the leaves of Rosa laevigata. Biorg Med Chem 21: 3290-3297, 2013

47. Losso JN, Bansode RR, Trappey A II, Bawadi HA and Truax R: In vitro antiproliferative activities of ellagic acid. J Nutr Biochem 15: 672-678, 2004.

48. Athokpam R, Bawari M and Choudhury MD: Hepatoprotective activity of aqueous extract of Pyrus pashia Buch.-Ham. Ex D. Don against $\mathrm{CCl}_{4}$ induced liver damage. Int J Pharm Sci Res 8: 4195-4200, 2017

49. Janbaz KH, Zaeem Ahsan M, Saqib F, Imran I, Zia-Ul-Haq M, Abid Rashid M, Jaafar HZ and Moga M: Scientific basis for use of Pyrus pashia Buch.-Ham. Ex D. Don fruit in gastrointestinal, respiratory, and cardiovascular ailments. PLoS One 10: e0118605, 2015.

50. Sharma P, Kumari A, Gulati A, Krishnamurthy S and Hemalatha S: Chrysin isolated from Pyrus pashia fruit ameliorates convulsions in experimental animals. Nutr Neurosci 22: 569-577, 2019.

51. Ain $\mathrm{Q}$ and Khan $\mathrm{H}$ : Pharmacological basis for sedative and hypnotic-like effects of Pyrus pashia using in vivo experimental models. Int J Geriatr Psychiatry 34: 1345-1350, 2019.

52. Giambò F, Italia S, Teodoro M, Briguglio G, Furnari N, Catanoso R, Costa C and Fenga C: Influence of toxic metal exposure on the gut microbiota. World Acad Sci J: 3, 2021 doi:10.3892/wasj.2021.90.

53. Negi BS, Chauhan DS and Todaria NP: Inventory of species richness of panchayat forests and adjoining reserve forests in three districts of Garhwal Himalaya, India. Trop Ecol 49: 121-129, 2008.

54. Decaprio AP: The toxicology of hydroquinone-relevance to occupational and environmental exposure. Crit Rev Toxicol 29: 283-330, 1999.

55. World map-Simple-MapChart. Retrieved 26th May 2019. Available from: https://mapchart.net/world.html.

56. Pyrus pashia-efloraofindia. Retrieved 2nd January 2021. Available from: https://sites.google.com/site/efloraofindia/species/m-z/r/rosaceae/pyrus/pyrus-pashia.

57. Gupta VK, Arya V and Gupta R: Pharmacognostic and phytochemical investigations on Pyrus Pashia Buch.-Ham. ex D. Don stem bark. J Chem Pharma Res 3: 447-456, 2011

This work is licensed under a Creative Commons Attribution-NonCommercial-NoDerivatives 4.0 International (CC BY-NC-ND 4.0) License. 